\section{ОРГАНІЗАЦІЙНО- ЕКОНОМІЧНЕ ЗАБЕЗПЕЧЕННЯ ЕНЕРГЕТИЧНОЇ НЕЗАЛЕЖНОСТІ АГРОПРОМИСЛОВОГО КОМПЛЕКСУ}

ГОНЧАРУК І.В., кандидат економічних наук, доцент кафедри економіки, Вінницький національний аграрний університет (м. Вінниця)

У статті агропромисловий комплекс досліджується як сектор, який залежить від перебігу природних процесів та його діяльність здійснюється із залученням величезної кількості енергії. Розкрито теоретичне бачення та категорії концептуалізачії змісту організаційно-економічного забезпечення енергетичної незалежності агропромислового комплексу. Запропоновано складові структури організачійно-економічного забезпечення енергетичної незалежності. Наведено аналоги терміну «сталий розвиток» та обтрунтовано застосування 3 категорією «сталий» використовувати й інші терміни, такі як «зрівноважений», «стійкий», «збалансований», «екорозвиток», «зелена економіка» та інші.

Проаналізовано ряд систем очінки та виміру практичного впровадження концепиіі «зеленої» економіки в економіки країн світу: глобальний індекс «зеленої» економіки, індекс низьковуглецевої економіки, індекс екологічної ефективності, глобальний індекс екологічно чистих інноваџій, вуглецеємність ВВП. Відмічено взаємозв'язок ВВП та емісії парникових газів у $\epsilon C$.

Інтерпретуючи концепцію «зеленої» економіки, запропоновано ввести в систему наукового пошуку категорію «зелена» енергетична незалежність - сукупність очіночних характеристик частини «зеленої», зокрема відновлюваної енергії у сукупному балансі. Зазначено, шьо озеленення енергетичної незалежності є також ефективним способом для розвитку господарських суб'єктів у рамках досягнення пріоритетів сталості.

Визначено, щуо енергетична незалежність $є$ комплексним сочіально-економічним явищем, яке характеризує статусні імперативи використання енергетичного потенціалу, а також стан економіки галузі в частині енергоефективності, енергозбереження, енергоощадності та енергозаміщення. Наведене базове спрямування обтрунтувань енергетичної незалежності аграрного сектору як досягнення інноваційності і цүілей сталого розвитку з проєкиією на всю систему життєдіяльності людини.

Ключові слова: енергетична незалежність, агропромисловий комплекс, сталий розвиток, «зелена» економіка, біопалива, енергоефективність, енергозбереження, енергоощадність, енергозаміщення.

Рис.: 2. Табл.: 3. Літ.: 22

\title{
ORGANIZATIONAL AND ECONOMIC SUPPORT OF ENERGY INDEPENDENCE OF AGRICULTURAL COMPLEX
}

HONCHARUK Inna, PhD in Economics, Associate Professor, Department of Economics, 


\section{Vinnytsia National Agrarian University (Vinnytsia)}

The article deals with the determining the agro-industrial complex as a sector that depends on the course of natural processes and its activity is carried out with the involvement of a huge amount of energy. The theoretical vision and categories of conceptualization of the content of organizational and economic support of energy independence of the agro-industrial complex are revealed. The components of the structure of organizational and economic support of energy independence are proposed. Analogues of the term «sustainable development» are given and the use of the term "sustainable» to use other terms, such as «balanced», "sustainable», "balanced», "environmental development», "green economy» and others.

A number of systems for assessing and measuring the practical implementation of the concept of "green» economy in the economies of the world are analyzed: the global index of "green» economy, low-carbon economy index, environmental efficiency index, global index of clean innovation, carbon intensity of GDP. It is noted the relationship between GDP and greenhouse gas emissions in the EU.

By interpreting the concept of "green» economy, it is proposed to introduce into the system of scientific research the category of "green» energy independence - a set of estimated characteristics of the "green", in particular renewable energy in the overall balance. It is noted that greening energy independence is also an effective way to develop businesses as part of achieving sustainability priorities.

It is determined that energy independence is a complex socio-economic phenomenon that characterizes the status imperatives for the use of energy potential, as well as the state of the economy in terms of energy efficiency, energy saving, energy saving and energy replacement. The basic direction of substantiation of energy independence of the agricultural sector as achievement of innovation and the purposes of sustainable development with a projection on all system of vital activity is resulted.

Key words: energy independence, agro-industrial complex, sustainable development, «green» economy, biofuels, energy efficiency, energy saving, energy saving, energy substitution.

Fig.: 2. Tabl.: 3. Lit.: 22

\section{ОРГАНИЗАЦИОННО-ЭКОНОМИЧЕСКОЕ ОБЕСПЕЧЕНИЕ ЭНЕРГЕТИЧЕСКОЙ НЕЗАВИСИМОСТИ АГРОПРОМЫШЛЕННОГО КОМПЛЕКСА}

\section{ГОНЧАРУК И.В., кандидат экономических наук, доцент кафедры экономики, Винницкий национальный аграрный университет} (2. Винница)

печения природных прочессов и их деятельность осуществляется с привлечением огромного количества энергии. Раскрыто теоретическое видение и категории конщептуализачии содержания организационно-экономического обеспечения энергетической независимости агропромышленного комплекса. Предложено составляющие структуры организационноэкономического обеспечения энергетической независимости. Приведены аналоги термина «устойчивое развитие» и обосновано применение с категорией «устойчивое» использовать и 
другие термины, такие как «контролированный», «стойкий», «сбалансированньй», «экоразвитие», «зеленая экономика» и другие.

Проанализирован ряд систем оценки и измерения практического внедрения концепции «зеленой» экономики в экономики стран мира: глобальный индекс «зеленой» экономики, индекс низкоуглеродной экономики, индекс экологической эффективности, глобальный индекс экологически чистых инноваций, углеродоемкость ВВП. Отмечено взаимосвязь ВВП и эмиссии парниковых газов в ЕС.

Интерпретируя концеепиию «зеленой» экономики, предложено ввести в систему научного поиска категорию «зеленая» энергетическая независимость - совокупность оценочных характеристик части «зеленой», в частности возобновляемой энергии в совокупном балансе. Отмечено, что озеленение энергетической независимости является также эффективным способом для развития хозяйственных субъектов в рамках достижения приоритетов устойчивости.

Определено, что энергетическая независимость является комплексным социальноэкономическим явлением, которое характеризует статусные императивы использования энергетического потенциала, а также состояние экономики отрасли в части энергоэффективности, энергосбережения, энергозамещения. Приведенное базовое направление обоснований энергетической независимости аграрного сектора как достижение инновационности и ичелей устойчивого развития с проекцичеи на всю систему жизнедеятельности человека.

Ключевые слова: энергетическая независимость, агропромышленный комплекс, устойчивое развитие, «зеленая» экономика, биотоплива, энергоэффективность, энергосбережение, энергоэффективность, енергозамищення.

Рис.: 2. Табл.: 3. Лит.: 22

Постановка проблеми. Галузеві реалії функціонування агропромислового комплексу пов'язані з природою. Даний сектор господарювання організаційно, ресурсно, а головне - результативно, залежить від перебігу природних процесів та відбувається із залученням величезної кількості енергії. Характер організації виробництва відзначається чіткою методологічною оцінкою специфіки засад організаційно-економічного забезпечення енергонезалежності. Постановка проблеми методично узгоджена 3 пріоритетами і критеріями сталого розвитку. Агропромисловий комплекс має ексклюзивні можливості створення й продуктивного використання біологічних, відновлюваних джерел енергії. Зазначене відіграє ключову роль для збалансування енергетичного критерію внутрішньогалузевим ресурсом. Ще одна методологічна ознака функціональної спроможності агропромислового комплексу у цьому напрямі полягає у забезпеченні енергоефективності, сприянні сталості та інноваційності, а також екологізації господарювання на землі. Заявлене вище $\epsilon$ методологічним підгрунтям для розкриття й оцінок засад організаційно-економічних умов досягнення енергетичної незалежності агропромислового комплексу. Питання вимагає удосконалення методичної бази пізнання, що досягається поглибленням та розширенням теоретичного бачення проблеми.

Аналіз останніх досліджень і публікацій. Із практики відомо й підтверджується у публікаціях вчених те, що пріоритетом для розвитку агропромислового комплексу завжди було i залишатиметься вирішення 
продовольчої проблеми. Відзначається, що: «будучи в минулому і залишаючись нині економічною базою трьох епох розвитку людства - аграрної, індустріальної та постіндустріальної - сільське господарство планети за останні десятиріччя крок за кроком набуває ознаки «стабільно зростаючого», як предтечі подолання глобальної продовольчої проблеми, яка настільки багатогранна й багатоаспектна, що фактично $є$ комплексом проблем, пов'язаних між собою й взаємно впливаючих одна на одну» [1, с. 8]. В. Криленко [2], у свою чергу, продовольчу безпеку методологічно ув'язує з енергетичною, що ми вважаємо питанням, яке у своєму вирішенні співвідноситься також із методологією формування енергетичної безпеки, а також енергетичної незалежності агропромислового комплексу. Забезпечення максимального рівня продовольчої незалежності $\epsilon$ визначальним у стратегіях розвитку агропромислового комплексу, але проблематика організаційно-економічного забезпечення енергетичної незалежності знаходить схвальні відгуки науковців [5], зокрема у концептуальному визначенні суті стратегій зеленого зростання і сталого розвитку на засадах відновлюваності ресурсів [7; 8]. Проте, додаткового вивчення вимагають питання сутнісних характеристик раціональної організаційно-інституційної побудови відносин із підтримки, сприяння формуванню енергетичної незалежності агропромислового комплексу.

Мета статті - розкрити теоретичне бачення змісту організаційноекономічного забезпечення енергетичної незалежності агропромислового комплексу.

Виклад основного матеріалу. Успішна реалізація концептуальних пріоритетів енергетичної незалежності агропромислового комплексу методологічно відповідає фактору сталості, адже галузь володіє креативним відновлювальним потенціалом. Таку аргументацію враховуємо при представленні методології обгрунтування засад формування енергетичної незалежності агропромислового комплексу, адже розроблені світовою спільнотою і визнані Організацією Об'єднаних Націй Цілі сталого розвитку до 2030 p. [10] - методологічний орієнтир у побудові стратегії, визначенні, пріоритетів, формуванні засад глобального життєвого процесу. Теоретично обгрунтованим і методологічно доведеним $є$ спосіб досягнення енергетичної незалежності за рахунок формування організованої системи виробництвавикористання біопалива, тобто розвитку відновлювальної енергетики, у тому числі за походженням із сільськогосподарської сировини. Відповідно методологічний базис енергетичної незалежності полягає у оцінках засад, критеріїв i чинників економічного, політичного, організаційного та інституційного спрямування, які забезпечують спроможність держави гарантувати стабільне постачання енергії суспільству в господарській системі.

Енергетична незалежність агропромислового комплексу, як досягнення відповідного стану і динаміки розвитку, відбувається в умовах й під впливом відповідного складу організаційно-економічних чинників або ж стимулів. Широкоформатність функцій агропромислового комплексу, який виступає 
природним гарантом формування цілого ряду забезпечуючих умов життєдіяльності людини, дає підстави вести дискусію про галузеву теорію і засади забезпечення енергетичної незалежності. Концепт пізнання піднятого питання полягає у тому, що енергетична незалежність аграрного сектору складна для досягнення, адже галузь функціонально вбудована в усі без виключення господарські процеси та ринкові механізми соціально-економічного обміну. Величезна сукупність чинників, які упорядковують критерії, результативність досягнення енергетичної незалежності - відносяться до підсистем організаційноекономічної спроможності досягти цієї стратегічної мети. Викристалізовується фактор організаційно-економічного забезпечення, який порівняно з ресурсним чинником, перебуває дещо на другому плані.

Критерії формування теоретичних основ розуміння сутності організаційно-економічного забезпечення енергетичної незалежності відповідають базовим критеріям характеристики економічних відносин у досліджуваній системі. Методологічна відповідність реалізується за витоками 3 теорії оргінізацій, управління, господарського механізму і ресурсовикористання.

Концептуалізація засад організаційно-економічного забезпечення, на базовому рівні розкриття його змісту, похідна від категорій: організація виробництва (господарювання); організація суспільного виробництва; організація управління; організація; інфраструктури ринку; організація ресурсовикористання (табл. 1).

Таблиия 1

Категорії концептуалізації змісту організаційно-економічного забезпечення енергетичної незалежності агропромислового комплексу

\begin{tabular}{|c|c|c|}
\hline Категорія & Зміст визначення сутності & $\begin{array}{c}\text { Характеристика відношення до } \\
\text { організаційно-економічного } \\
\text { забезпечення енергонезалежності }\end{array}$ \\
\hline $\begin{array}{l}\text { Організаційн } \\
\text { о-економічні } \\
\text { відносини }\end{array}$ & $\begin{array}{l}\text { «Відносини між людьми } 3 \text { приводу організації } \\
\text { безпосереднього виробництва (у т.ч. обміну, розподілу і } \\
\text { споживання) матеріальних благ і послуг» }[11, \text { с. } 27]\end{array}$ & $\begin{array}{l}\text { Ідентифікація організаційно- } \\
\text { економічного процесу }\end{array}$ \\
\hline $\begin{array}{c}\text { Організація } \\
\text { виробництва } \\
\text { (господарюва } \\
\text { ння) }\end{array}$ & $\begin{array}{l}\text { «Об’єднання працівників } 3 \text { метою спільного } \\
\text { виготовлення товарів, надання послуг, виконання робіт } \\
\text { на підставі певних принципів, форм і методів» }[11, \text { с. } \\
\text { 29] }\end{array}$ & $\begin{array}{l}\text { Ідентифікація складових } \mathrm{i} \\
\text { функціональних } \quad \text { характеристик } \\
\text { господарського механізму }\end{array}$ \\
\hline $\begin{array}{l}\text { Організація } \\
\text { суспільного } \\
\text { виробництва }\end{array}$ & $\begin{array}{l}\text { «Координація дій кожної зі сторін суспільного способу } \\
\text { виробництва та процесу їх взаємодії і форми об’єднання } \\
\text { людей у процесі такого виробництва... Двома } \\
\text { сторонами суспільного виробництва } є \text { продуктивні } \\
\text { сили і відносини економічної власності» }[11, \text { с. } 31]\end{array}$ & $\begin{array}{lrr}\text { ддентифікація } & \text { потреби } \\
\text { енергетичних } & \text { ресурсах за } \\
\text { наслідками } & \text { рівня розвитку } \\
\text { продуктивних } & \text { сил і виробничих } \\
\text { відносин } & \end{array}$ \\
\hline $\begin{array}{l}\text { Організація } \\
\text { управління }\end{array}$ & $\begin{array}{l}\text { «Процес створення досконалішої системи управління або } \\
\text { впровадження прогресивних якісних і сутнісних змін у } \\
\text { структуру і порядок функціонування та розвиток раніше } \\
\text { створеної діючої системи управління з метою поліпшення } \\
\text { якості організації та реалізації поставлених перед нею } \\
\text { цілей» [11, с. } 31]\end{array}$ & $\begin{array}{l}\text { Ідентифікація } \quad \text { ефективності } \\
\text { управління як чинника впливу на } \\
\text { залучення i } \quad \text { використання } \\
\text { енергетичних ресурсів }\end{array}$ \\
\hline $\begin{array}{l}\text { Організація } \\
\text { інфраструкту } \\
\text { ри ринку }\end{array}$ & $\begin{array}{lccc}\text { Формування } & \text { i забезпечення організаційно- } \\
\text { економічного } & \text { функціонування структур сприяння } \\
\text { здобуття-накопичення-розподілу енергії } & \end{array}$ & $\begin{array}{ll}\text { Ідентифікація } & \text { складових } \\
\text { механізму здобуття і розподілу } \\
\text { енергії }\end{array}$ \\
\hline
\end{tabular}

Джерело: систематизовано і доповнено автором на основі опрацювання літературних джерел [11, с. 27-31] 
3 аналізу наукових положень вибудовується теоретико-методична схема концепту формування поняття «організаційно-економічне забезпечення енергетичної незалежності агропромислового комплексу». Логічним є поділ організаційно-економічного забезпечення на дві взаємопов'язані складові організаційне і економічне (рис. 1).

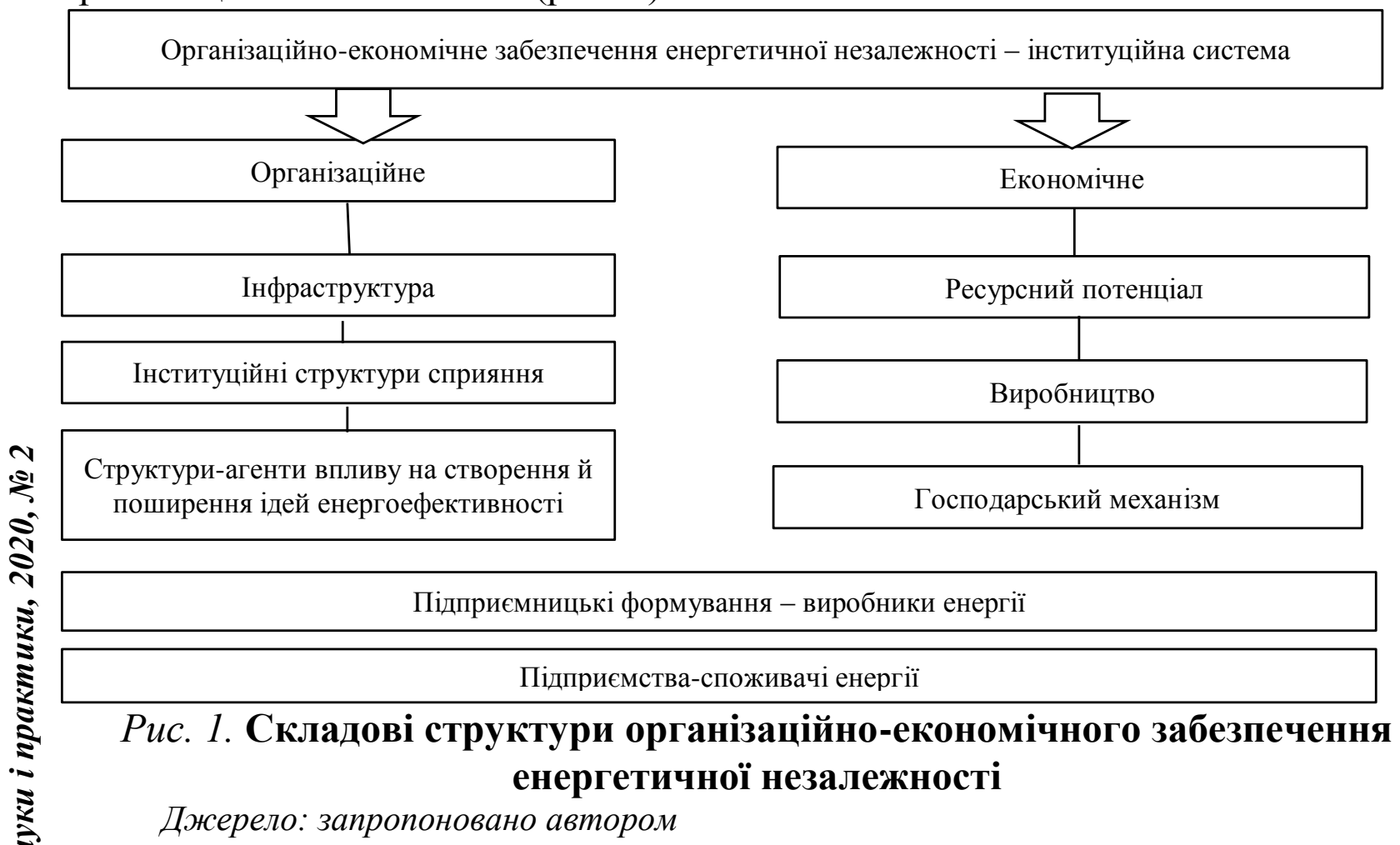

Організаційно-економічне забезпечення формує стимули формування енергетичної незалежності агропромислового комплексу. У макроекономічному сенсі визначення організаційно-економічних стимулів забезпечення енергетичної незалежності важливо відзначити значущість чинника ринку біопалив як організаційно-економічного механізму саморегулювання в системі енерговикористання. Даний ринок - складна система координації економічних взаємодій, середовище вартісно опосередкованого обміну таким специфічним товаром, як біопаливо. Проте, за пріоритетом методичних основ дослідження, за базу беремо теоретичну модель «зеленої» економіки, оскільки деякі дослідники вважають невдалим застосування терміну «сталий розвиток». Категорії «сталість» і «розвиток», на перший погляд, не сумісні. Як відомо, розвиток - це незворотна, цілеспрямована, закономірна зміна системи. I хоча сам термін «розвиток» передбачає упорядкованість, у поєднанні 3 терміном «сталий» посилюється визначена цілеспрямованість, векторність змін системи, йдеться про конкретну модель розвитку, як справедливо зазначає О. Попова [3].

Тому разом із категорію «сталий» пропонуються й інші терміни, такі як «зрівноважений», «стійкий», «збалансований», «екорозвиток», «зелена економіка» та інші (табл. 2), що в цілому, незважаючи на деякі відмінності, характеризують одне й те ж саме поняття. Термін «зелена економіка» набуває 
все більшої популярності. Зокрема, його використовують у підсумковій резолюції «Майбутнє, якого ми прагнемо» [4] Конференції з питань сталого розвитку, відомої під назвою «Ріо+20», яка пройшла у м. Ріо-де-Жанейро (Бразилія) у 2012 р.

Таблиия 2

Аналоги терміну «сталий розвиток»

\begin{tabular}{|c|c|}
\hline Вчені, установи & Пропонований аналог терміну «сталий розвиток» \\
\hline М. Стронг & $\begin{array}{l}\text { «екорозвиток» - екологічно орієнтований соціально-економічний розвиток, при якому } \\
\text { зростання добробуту людей не супроводжується погіршенням середовища існування та } \\
\text { деградацією природних систем }\end{array}$ \\
\hline П. Олдак & $\begin{array}{l}\text { «рівноважне природокористування» - коли суспільство контролює всі сторони свого } \\
\text { розвитку, намагаючись, щоб сукупне антропогенне навантаження на середовище не } \\
\text { перевищувало самовідновного потенціалу природних систем }\end{array}$ \\
\hline А. Ісаченко & $\begin{array}{l}\text { «оптимізація природного середовища» - комплекс заходів щодо раціонального використання } \\
\text { природних ресурсів, охорони, оздоровлення й узагальнення природного оточення людства }\end{array}$ \\
\hline А. Москаленко & $\begin{array}{l}\text { «рівноважне природокористування» - передбачає неперевищення сумарного антропогенного } \\
\text { навантаження потенціалу самовідновлення природного середовища та/або окремих територій }\end{array}$ \\
\hline Л. Мельник & $\begin{array}{l}\text { «екологізація» - процес неухильного та послідовного впровадження систем технологічних, } \\
\text { управлінських та інших рішень, що дають змогу підвищувати ефективність використання } \\
\text { природних ресурсів з одночасним збереженням або поліпшенням природного середовища (або } \\
\text { взагалі життя) на локальному, регіональному та глобальному рівнях }\end{array}$ \\
\hline О. Єфремов & $\begin{array}{l}\text { «гармонійний (з екосистемою) розвиток» - історичний процес, де корисна потужність } \\
\text { екосистеми забезпечує неубуваючі темпи зростання життєзабезпечення людства при } \\
\text { екологічній нормалі (нормальний для життєзабезпечення суспільства стан). Тобто } \\
\text { передбачається збереження гармонії між суспільством і природою, за якої природне } \\
\text { навколишнє середовище зберігається у нормальномудля життєзабезпечення суспільства стані } \\
\text { та створює умови для формування певних принципів життя і розвитку суспільства }\end{array}$ \\
\hline I. Синякевич & $\begin{array}{l}\text { «екологізація суспільного розвитку»- об’єктивний процес протидії глобальним екологічним } \\
\text { загрозам в екологічній, економічній, соціальній і духовній сферах і трансформації } \\
\text { споживацької природо руйнуючої ментальності людей у природо ощадну, а економічних } \\
\text { інструментів - в інструменти екологічної політики }\end{array}$ \\
\hline $\begin{array}{l}\text { Д. Пірс, } \\
\text { А. Маркандія, } \\
\text { Е. Барб’є }\end{array}$ & «зелена економіка» - це допомога економіці в реалізації екологічної політики \\
\hline $\begin{array}{l}\text { Програма ООН } 3 \\
\text { навколишнього } \\
\text { середовища } \\
\text { (ЮНЕП) }\end{array}$ & $\begin{array}{l}\text { Зеленою є така економіка, яка призводить до підвищення добробуту людей і зміцнення } \\
\text { соціальної справедливості при одночасному істотному зниженні ризиків для навколишнього } \\
\text { середовища та дефіциту екологічних ресурсів }\end{array}$ \\
\hline
\end{tabular}

На наше переконання, концепт «зеленої» платформи органічно вписується у методичну конструкцію визначення організаційно-економічних чинників формування енергетичної незалежності - на що звертають увагу сучасні дослідники [13] і в цьому аспекті ми їх загалом підтримуємо. Адже теоретична платформа «зеленої» економіки моделює організаційну складову у обгрунтуваннях концепції визначення енергетичної незалежності як інституційної системи. 3 цього питання цікавим вважаємо Свропейський досвід, адже законодавством ЄC країнам запропоновані основні комунікативні платформи, за допомогою яких вибудовується необхідна інституційна система $\mathrm{i}$ поширюються знання про «зелене» зростання. Що, у свою чергу, пов’язано 3 формуванням енергетичної незалежності на засадах активного розвитку відновлюваної енергетики. 
Сьогодні існує ряд систем оцінки та виміру практичного впровадження концепції «зеленої» економіки. Так, у 2009 р. міжнародна організація (Global Real Estate Sustainability Benchmark - далі GRESB) опублікувала першу систему оцінок сталого розвитку та дотримання принципів ESG. Методологія GRESB дозволяє проводити моніторинг інфраструктурних проєктів, включаючи енергетику, передачу електроенергії, водовідведення, транспорт, соціальну інфраструктуру, телекомунікації. Під час розрахунку рейтингу GRESB спирається на показники якості менеджменту, політики розкриття інформації, профіль ризиків, показники роботи компанії-оператора тощо.

Серед інших систем оцінки:

- система еколого-економічного обліку ООН (United Nations' System of Environmental-Economic Accounting, SEEA) [14], що стала глобальною спробою запровадити узгоджені стандарти бухгалтерського обліку, якою вимірюється фінансова прихильність економіки до охорони навколишнього середовища. Дана

$$
\text { exo }
$$
чотирма показниками [16]: форумах, результати зміни клімату); iH.);

2) ефективність галузей (будівництво, транспорт, енергетика, туризм та

3) ринки та інвестиції (ВДЕ, екотехнології, стимулювання екологічних інвестицій, корпоративна стабільність); 
4) довкілля (сільське господарство, якість повітря та води, біологічне та природне середовище, рибальство, ліси).

GGEI - перший індекс «зеленої» економіки, який, на сьогодні, $\epsilon$ продуктом, на який посилається міжнародна спільнота: політики, міжнародні організації, громадянське суспільство та приватний сектор. Індекс слугує основою для створення індивідуальних систем вимірювання сталості та “зеленості" економік світу.

Ще один індекс - Індекс низьковуглецевої економіки (The Low Carbon Economy Index), який розроблено консалтинговою компанією Pricewaterhouse Coopers y 2000 p. Індекс дозволяє оцінити поступ країни G20 у частині скорочення рівня інтенсивності викидів вуглецю. Показник визначається як співвідношення обсягу викидів вуглецю до ВВП за відповідний рік $\left(\mathrm{CO}_{2}\right.$ у т/ВВП у \$ млн.), а на його результат впливають такі фактори, як енергоефективність, витрата пального, щільність населення, структура економіки в країні та стан кліматичної системи.

Ще одним важливим індикатором, на наш погляд, є Індекс екологічної ефективності (Environmental Performance Index - далі EPI) - комплексний показник оцінки екологічної політики держави та іï окремих суб'єктів. Індекс розраховується за 24 показниками ефективності по десятьох категоріях, що охоплюють стан здоров'я, навколишнє середовище та життєздатність екосистеми. Ці показники дають змогу оцінити, наскільки країни досягли встановлених цілей екологічної політики. Протягом багатьох років лідером залишається Швейцарія - країна, яка 3 кожним роком підвищує свої результати (зокрема, у 2012 р. показник становив 76,2\%). Україна ж у 2018 р. посіла 109-е місце серед 132 країн світу з показником у 52,87\%. Низькі показники свідчать про необхідність посилення зусиль держави щодо забезпечення сталого розвитку за рядом факторів, наприклад, захист біорізноманіття, скорочення викидів ПГ тощо.

Дотичним до екології є Глобальний індекс екологічно чистих інновацій (Global Cleantech innovation Index), який було створено у 2012 р. Індекс розраховується по 40 країнах світу як зважена сума оцінок двох груп показників: наявні ресурси та умови для проведення інновацій (Inputs to Innovation) та досягнуті практичні результати здійснення інновацій (Outputs of Innovation). Підсумковий індекс являє собою співвідношення витрат на розвиток інновацій $\mathrm{i}$ отриманого ефекту [17].

Порівняно 3 «зеленою» економікою, яка меншою мірою піддається кількісній оцінці, сьогодні можливо оцінити результативність «низьковуглецевого» розвитку, який у більшості випадків трактується як процес відокремлення економічного зростання від зростання споживання енергії та викидів парникових газів, завдяки технологічним інноваціям, зміні інфраструктури та моделі поведінки економічних суб'єктів. Одним із факторів, що характеризує рух країни шляхом низьковуглецевого розвитку, $є$ зниження рівня вуглецеємності ВВП [18]. Так, завдяки змінам у структурі економіки 
(переходу від енергоємного виробництва 3 низькою доданою вартістю до високотехнологічного), впровадженню нових технологій, заходів із енергозбереження як на рівні держави, так і на рівні окремих домогосподарств, інтенсивному розвитку відновлювальних джерел енергії, відбулося значне зниження вуглецеємності ВВП серед країн світу (табл. 3).

Таблиия 3

\section{Показники оцінки та виміру «зеленої» економіки}

\begin{tabular}{|c|c|c|c|c|c|c|c|c|c|c|}
\hline \multirow{2}{*}{$\begin{array}{c}\text { Країна } \\
\text { (територія) }\end{array}$} & \multicolumn{2}{|c|}{$\begin{array}{c}\text { Глобальний } \\
\text { індекс } \\
\text { «зеленої» } \\
\text { економіки } \\
\text { (2018 р.) }\end{array}$} & \multicolumn{2}{|c|}{$\begin{array}{c}\text { Індекс } \\
\text { низько- } \\
\text { вуглецевої } \\
\text { економіки } \\
\text { (2019 р.) }\end{array}$} & \multicolumn{4}{|c|}{$\begin{array}{l}\text { Індекс екологічної ефективності } \\
\text { (2018 р.) }\end{array}$} & \multirow{2}{*}{$\begin{array}{c}\text { Глобальний } \\
\text { індекс } \\
\text { екологічно } \\
\text { чистих } \\
\text { інновацій } \\
\text { (2017 р.) }\end{array}$} & \multirow{2}{*}{$\begin{array}{c}\text { Вуглеце- } \\
\text { ємність } \\
\text { ВВП } \\
\left(\mathrm{CO}_{2} / \mathrm{BВП}\right. \\
(\text { (а ПКС)), } \\
\text { кг } \mathrm{CO}_{2} / \$ \\
(2016 \text { р.) }\end{array}$} \\
\hline & 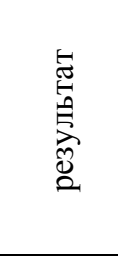 & 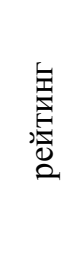 & 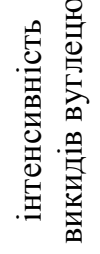 & 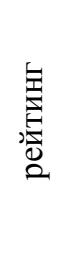 & 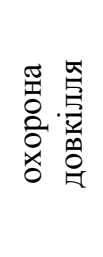 & 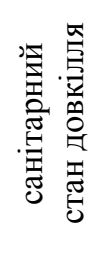 & 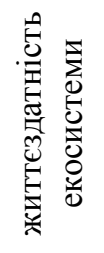 & 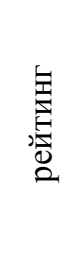 & & \\
\hline Швеція & 0,7608 & 1 & & & 80,51 & 94,41 & 71,24 & 5 & 3,86 & \\
\hline Швейцарія & 0,7594 & 2 & & & 87,42 & 93,57 & 83,32 & 1 & & \\
\hline Ісландія & 0,7129 & 3 & & & & & & & & \\
\hline Норвегія & 0,7031 & 4 & & & & & & & & \\
\hline Фінляндія & 0,6997 & 5 & & & & & & & 3,96 & \\
\hline Німеччина & 0,6890 & 6 & & & & & & & & 0,21 \\
\hline Данія & 0,6800 & 7 & & & 81,60 & 98,20 & 70,53 & 3 & 4,07 & \\
\hline Тайвань & 0,6669 & 8 & & & & & & & & \\
\hline Австрія & 0,6479 & 9 & & & & & & & & \\
\hline Франція & 0,6405 & 10 & 107 & 1 & 83,95 & 95,71 & 76,11 & 2 & & 0,12 \\
\hline Україна & 0,3813 & 120 & & & 52,87 & 64,44 & 45,16 & 109 & & 0,62 \\
\hline $\begin{array}{c}\text { Велика } \\
\text { Британія }\end{array}$ & & & 128 & 2 & & & & & & 0,15 \\
\hline Італія & & & 131 & 3 & & & & & & \\
\hline Бразилія & & & 137 & 4 & & & & & & \\
\hline Індонезія & & & 154 & 5 & & & & & & \\
\hline $\begin{array}{l}\text { Саудівська } \\
\text { Аравія }\end{array}$ & & & 365 & 16 & & & & & & \\
\hline Китай & & & 378 & 17 & & & & & & 0,47 \\
\hline $\begin{array}{c}\text { Південна } \\
\text { Корея }\end{array}$ & & & 387 & 18 & & & & & & \\
\hline Росія & & & 402 & 19 & & & & & & 0,45 \\
\hline ПАР & & & 519 & 20 & & & & & & \\
\hline Мальта & & & & & 80,90 & 93,80 & 72,30 & 4 & & \\
\hline Канада & & & & & & & & & 3,76 & 0,35 \\
\hline США & & & & & & & & & 3,59 & 0,29 \\
\hline Японія & & & & & & & & & & 0,24 \\
\hline Індія & & & & & & & & & & 0,26 \\
\hline
\end{tabular}

Джерело: сформовано автором за даними [17]

На прикладі ЄС можна також побачити, що поступово відбувається послаблення взаємозв'язку емісії парникових газів та ВВП. Починаючи з 2010 р., відбувалося зростання рівня промисловості та активізація економічної діяльності, що сприяли відновленню економіки СС та зростанню загального рівня ВВП. Це, своєю чергою, могло б збільшити викиди парникових газів, проте 
цього не сталося. Навпаки їх викиди, у цілому, скоротилися, особливо у секторах, охоплених Системою торгівлі викидами в СС. Загалом, у період з 1990 р. до 2017 p., сукупний ВВП $\mathrm{CC}$ зріз на 55\%, а загальний обсяг викидів парникових газів зменшився на $24 \%$ (рис. 2) [19, 20].

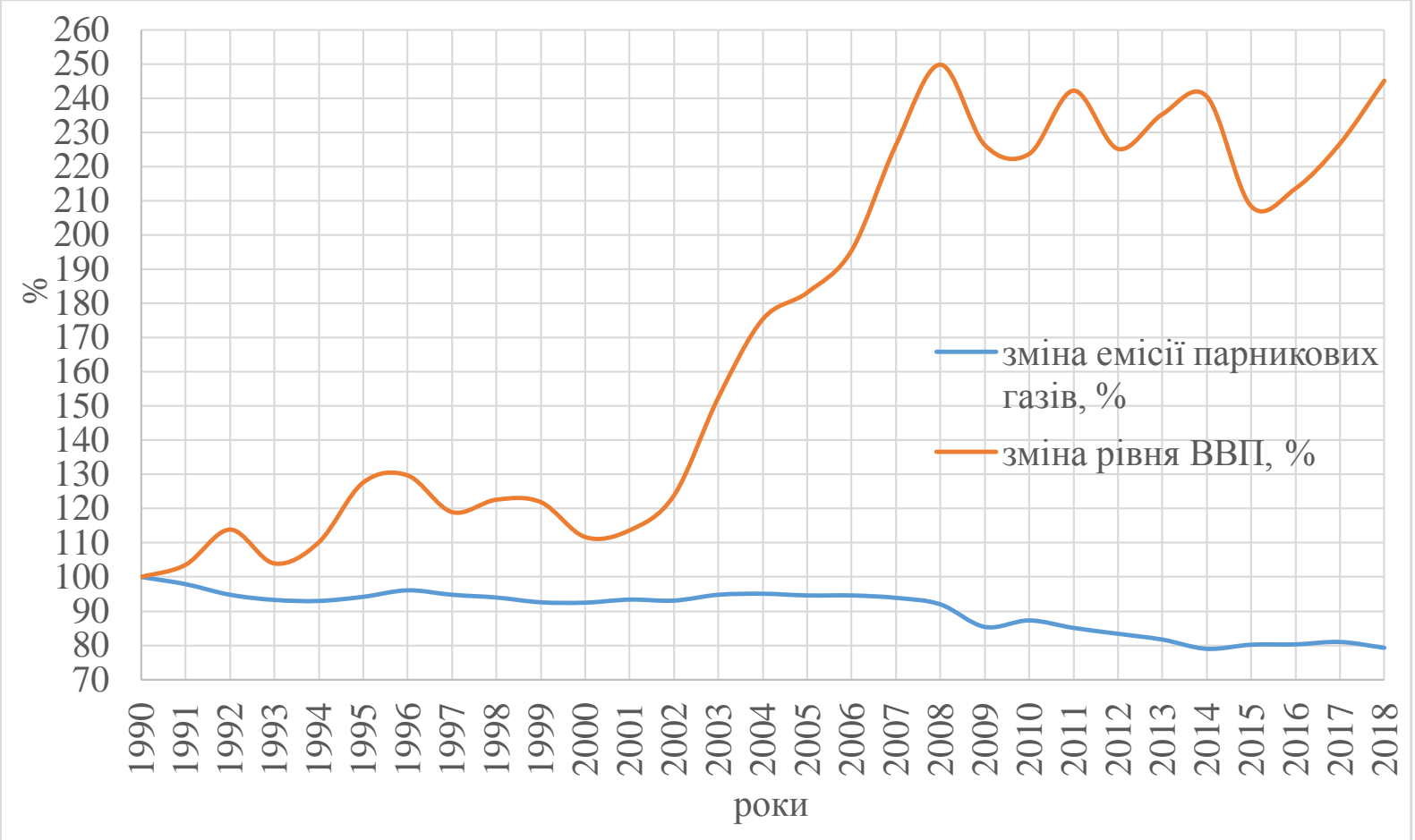

\section{Рис. 2. Взаємозв'язок ВВП та емісії парникових газів у СС $(1990$ p. $=100 \%)$}

Джерело: розраховано автор за даними Eurostat [19], The World Bank [20]

Мова також повинна обов'язково йти про підприємництво як чинник формування енергетичної незалежності. «Зелене» сільськогосподарське підприємництво, тобто здійснюване 3 широкоплановим використанням відновлюваних джерел енергії, опосередковано виступає саморегулівним стимулом для досягнення «зеленої» енергетичної незалежності. Інтерпретуючи концепцію «зеленої» економіки доцільно ввести в систему наукового пошуку категорію «зелена» енергетична незалежність. Коментуємо зміст цього поняття як сукупність оціночних характеристик частини «зеленої», зокрема відновлюваної енергії у сукупному балансі. Озеленення енергетичної незалежності $\epsilon$ також ефективним способом для розвитку господарських суб'єктів у рамках досягнення пріоритетів сталості.

Еволюція засад організації економічної, головним чином господарської діяльності людини, відбувалася і відбувається в рамках та під дією чинників науково-технічного прогресу. Людство пройшло тривалий шлях свого існування, перш ніж було усвідомлено необхідність утвердження господарських систем, суспільно-економічних відносин, побудованих із дотриманням закону сталості. Наукова спільнота твердо стоїть на позиціях поглиблення теоретикометодологічних засад сталого розвитку, у тому числі з пріоритетом урахування 
чинника відновлюваності ресурсів. Обов'язкове використання чинника відновлюваності зустрічається в концепціях організацій та забезпечення економічних. соціальних, господарських, енергетичних систем. Енергетична незалежність як статусний імператив оцінки стану економіки, галузі, позиціонується 3 активним поширенням ідей про значну роль у їі формуванні відновлюваних джерел енергії. Таку позицію відстоюють цілий ряд вітчизняних i зарубіжних дослідників. Зокрема вона методологічно актуалізована. Вмотивованість поширення ідеології відновлюваних джерел енергії для визначення концепції побудови енергонезалежної економіки відповідає критерію наявності, зокрема в агропромисловому комплексі, значного потенціалу виробництва відновлюваної енергії.

Усвідомлення наукою і підтвердження практикою виключно важливої ролі відновлюваних джерел енергіï у формуванні енергетичної незалежності економіки пов'язують із рядом переваг, зокрема у реалізації концепції економічних відносин на засадах сталого розвитку. Серед переваг, зокрема для аграрного сектору: енергетична автономізація галузі; зменшення впливу чинника сезонності; стабілізація вартісної складової формування конкурентоспроможності галузі за рахунок оптимізації чинника вартості енергії; покращення екології; додаткове завантаження потужностей переробної промисловості.

Від початку зародження цивілізації людина, як кожна жива істота, використовує енергію, котра надходить до їі організму з продуктами харчування рослинного та тваринного походження. Ця енергія може накопичуватись в організмі або зразу ж витрачатись для росту та функціонування самого живого людського організму, перебігу в ньому обмінних процесів, використання м'язової енергії для здійснення рухів як окремих частин тіла, так і всього організму.

Висновки. Вважаємо, що енергетична незалежність $є$ комплексним соціально-економічним явищем, яке характеризує статусні імперативи використання енергетичного потенціалу, а також стан економіки галузі в частині енергоефективності, енергозбереження, енергоощадності та енергозаміщення. Практично вона поєднує економічне і соціальне начало, механізми відповідного балансування економічних вигод та соціальної відповідальності. Названа ідеологія консолідовано поширюється, у методологічному плані сприйняття, на сферу політичних, економічних, а також соціальних ефектів. Базове спрямування обгрунтувань енергетичної незалежності аграрного сектору - досягнення інноваційності і цілей сталого розвитку 3 проєкцією на всю систему життєдіяльності людини. Методологічне підгрунтя цього висновку усвідомлена людством ідея про те, що сільське господарство, село, аграрний сектор - взаємодоповнювані компоненти, які формують відповідне середовище життя і господарювання. Проте, вносячи власні теоретико-методологічні висновки, зауважимо, що енергетична незалежність органічно пов'язана 3 енергетичною безпекою, i походить із засад та стану процесів побудови 
енергоефективної моделі господарювання. Ця модель структурована в рамках потенціалу галузі, а також залежить від пріоритетів інституційної політики в системі державного менеджменту.

\section{Список використаних джерел}

1. Формування глобального і регіонального ринків сільськогосподарської сировини та продовольства : монографія / Ю.О. Лупенко, М.І. Пугачов, Б.В. Духницький та ін. ; за ред. Ю.О. Лупенка, М.І. Пугачова. Київ, 2015. 320 с.

2. Криленко В.I. Економічна безпека аграрного сектору: проблеми регулювання та забезпечення : монографія. Миколаїв, 2014. 468 с.

3. Попова О.Л. Сталий розвиток агросфери України : політика і механізми / О.Л. Попова. - К. : Ін-т екон. та прогнозув. НАНУ, 2009. - 352 с.

4. Бородіна О.М., Геєць В.М., Гуторов А.О. та ін. Українська модель аграрного розвитку та її соціоекономічна переорієнтація : наук. доп. - К. : Ін-т екон. та прогнозув. НАН України, 2012. - 54 с.

5. Калетнік Г.М. Виробництво і використання біопалив: Підручник. Вінниця. 2015. 408 с.

6. Калетнік Г.М. Диверсифікація розвитку виробництва біопалив - основа забезпечення продовольчої, енергетичної, економічної та екологічної безпеки України. Вісник аграрної науки, 2018. №11. С. 169-176. DOI: https://doi.org/10.31073/agrovisnyk201811-21

7. Наукові основи і стратегічні пріоритети сталого розвитку сільських територій України /[Гадзало Я.М., Жук В.М., Могилова М.М., Шпикуляк О.Г. та ін.]; за ред. Я.М. Гадзала. - К.: ННЦ «ІАЕ», 2019. 40 с.

8. Малік М., Шпикуляк О., Мамчур В. Реалізація цілей сталого розвитку України в контексті трансформації особистих селянських господарств у сімейні фермерські. Економіка природокористування і сталий розвиток. 2020. №7(26). C. 21-31

9. Гончарук I.В. Енергетична незалежність як суспільно-економічне явище. Економіка та держава. 2020. № 8. C. 71-77. DOI: 10.32702/2306-6806.2020.8.71

10. Стратегія сталого розвитку України до 2030 року URL: file:///C:/Users/Work/Downloads/UNDP_Strategy_v06-optimized\%20(1).pdf (дата звернення 07.06.2020)

11. Економічний енциклопедичний словник : у 2-х т. Т. 2 / за ред. С.В. Мочерного. Львів : Світ, 2006. 568 с.

12. Лопатинський Ю.М., Тодорюк С.І. Детермінанти сталого розвитку аграрних підприємств : [монографія] / Ю.М. Лопатинський, С.І. Тодорюк. Чернівці : Чернівецький нац. ун-т, 2015. - 220 с.

13. Ходаківська О.В., Шпикуляк О.Г. Інститути «зеленої» економіки у забезпеченні сталого розвитку агросектору : теоретичний вимір. Бізнес-Інформ. 2017. №9. C. 13-18

14. The official website of the System of Environmental Economic Accounting. URL: https://seea.un.org/ (дата звернення 20.07.2020). 
15. The official website of the Organization for Economic Co-operation and Development.

URL: https://stats.oecd.org/Index.aspx?DataSetCode=GREEN_GROWTH (дата звернення 20.07.2020).

16. The official website of the Dual Citizen. URL: https://dualcitizeninc.com/global-green-economy ndex/index.php\#interior_section_link. (дата звернення 20.07.2020).

17. Маркевич К., Сіденко В. “Зелені” інвестиції у сталому розвитку: світовий досвід та український контекст. URL: https://razumkov.org.ua/uploads/article/2019_ZELEN_INVEST.pdf

18. The official website of the International Energy Agency. URL: https://www.iea.org/areas-of-work/global-engagement (дата звернення 20.07.2020).

19. The official website of the Eurostat. URL: https://ec.europa.eu/eurostat/statisticsexplained/index.php/Greenhouse_gas_emission_statistics 19.07.2020).

20. The official website of the World Bank. URL: https://data.worldbank.org/indicator/NY.GDP.MKTP.KD.ZG?locations=EU (дата звернення 18.07.2020).

21. Гончарук I.В. Виробництво біогазу в аграрному секторі - шлях до підвищення енергетичної незалежності та родючості грунтів. Агросвіт. 2020. № 15. C. 18-29. DOI: 10.32702/2306-6792.2020.15.18

22. Гончарук І.В. Роль сільськогосподарських кооперативів у забезпеченні сталого розвитку сільських територій Вінницької області. Економіка, фінанси, менеджмент: актуальні питання науки і практики. 2017. №8(24). С. 56-67

\section{References}

1. Lupenko, Yu.O., Pugachov, M.I., \& Duxnyczkyj, B.V. (2015). Formuvannya globalnogo $i$ regionalnogo rynkiv silskogospodarskoyi syrovyny ta prodovolstva [Formation of global and regional markets for agricultural raw materials and food]. Kyiv [in Ukrainian].

2. Krylenko, V.I. (2014). Ekonomichna bezpeka agrarnogo sektoru: problemy regulyuvannya ta zabezpechennya [Economic security of the agricultural sector: problems of regulation and provision]. Mykolayiv [in Ukrainian].

3. Popova, O.L. (2009). Stalyj rozvytok agrosfery Ukrayiny: polityka $i$ mexanizmy [Sustainable development of Ukraine's agrosphere: policy and mechanisms]. Kyiv: Instytut ekonomiky ta prognozuvannya NANU [in Ukrainian].

4. Borodina, O.M., Geyecz, V.M., Gutorov, A.O. et. al. (2012). Ukrayinska model agrarnogo rozvytku ta yiyi socioekonomichna pereoriyentaciya [Ukrainian model of agrarian development and its socio-economic reorientation]. Kyiv: Instytut ekonomiky ta prognozuvannya NAN Ukrayiny [in Ukrainian].

5. Kaletnik, G.N. (2015). Vyrobnycztvo i vykorystannya biopalyv [Production and use of biofuels]. Vinnytsia [in Ukrainian]. 
6. Kaletnik, G.N. (2018). Dyversyfikatsiia rozvytku vyrobnytstva biopalyv osnova zabezpechennia prodovolchoi, enerhetychnoi, ekonomichnoi ta ekolohichnoi bezpeky Ukrainy [Diversification of biofuel production development is the basis for ensuring food, energy, economic and environmental security of Ukraine]. Visnyk ahrarnoi nauky - Bulletin of Agricultural Science, 11, 169-176. Retrieved from DOI: https://doi.org/10.31073/agrovisnyk201811-21 [in Ukrainian].

7. Hadzalo, Ya.M., Zhuk, V.M., Mohylova, M.M., Shpykuliak, O.H. et. al. (2019). Naukovi osnovy i stratehichni priorytety staloho rozvytku silskykh terytorii Ukrainy [Scientific bases and strategic priorities of sustainable development of rural areas of Ukraine]. Kyiv: NNTs «IAE» [in Ukrainian].

8. Malik, M., Shpykuliak, O., \& Mamchur, V. (2020). Realizatsiia tsilei staloho rozvytku Ukrainy v konteksti transformatsii osobystykh selianskykh hospodarstv u simeini fermerski [Realization of the goals of sustainable development of Ukraine in the context of transformation of personal peasant farms into family farms]. Ekonomika pryrodokorystuvannia $i$ stalyi rozvytok - Economics of nature management and sustainable development, 7(26), 21-31 [in Ukrainian].

9. Honcharuk, I.V. (2020). Enerhetychna nezalezhnist yak suspilnoekonomichne yavyshche [Energy independence as a socio-economic phenomenon]. Ekonomika ta derzhava - Economy and state, 8, 71-77. Retrieved from DOI: 10.32702/2306-6806.2020.8.71 [in Ukrainian].

10. Stratehiia staloho rozvytku Ukrainy do 2030 roku [Strategy of sustainable development of Ukraine until 2030] Retrieved from: file:///C:/Users/Work/Downloads/UNDP_Strategy_v06-optimized\%20(1).pdf (data zvernennia 07.06.2020) [in Ukrainian].

11. Mochernyi, S.V. (Eds.) (2006). Ekonomichnyi entsyklopedychnyi slovnyk [Economic encyclopedic dictionary]. (Vols. 1-2). Lviv: Svit [in Ukrainian].

12. Lopatynskyi, Yu.M., \& Todoriuk, S.I. (2015). Determinanty staloho rozvytku ahrarnykh pidpryiemstv [Determinants of sustainable development of agricultural enterprises]. Chernivtsi: Chernivetskyi natsionalnyi universytet [in Ukrainian].

13. Khodakivska, O.V., \& Shpykuliak, O.H. (2017). Instytuty "zelenoi" ekonomiky u zabezpechenni staloho rozvytku ahrosektoru: teoretychnyi vymir [Institutions of "green" economy in ensuring sustainable development of the agricultural sector: a theoretical dimension]. Biznes-Inform - Business Inform, 9, 1318 [in Ukrainian].

14. The official website of the System of Environmental Economic Accounting. Retrieved from: https://seea.un.org/ (data zvernennia 20.07.2020) [in English].

15. The official website of the Organization for Economic Cooperation and Development. Retrieved from: https://stats.oecd.org/Index.aspx?DataSetCode=GREEN_GROWTH (data zvernennia 20.07.2020) [in English].

16. The official website of the Dual Citizen. Retrieved from: https://dualcitizeninc.com/global-green-economy- 
index/index.php\#interior_section_link. (data zvernennia 20.07.2020) [in English].

17. Markevych, K., \& Sidenko. V. (2019). "Zeleni" investytsii u stalomu rozvytku: svitovyi dosvid ta ukrainskyi kontekst [Green investments in sustainable development: world experience and Ukrainian context]. Retrieved from: https://razumkov.org.ua/uploads/article/2019_ZELEN_INVEST.pdf [in Ukrainian].

18. The official website of the International Energy Agency. Retrieved from: https://www.iea.org/areas-of-work/global-engagement (data zvernennia 20.07.2020) [in English].

19. The official website of the Eurostat. Retrieved from: https://ec.europa.eu/eurostat/statistics-

explained/index.php/Greenhouse_gas_emission_statistics (data zvernennia 19.07.2020) [in English].

20. The official website of the World Bank. Retrieved from: https://data.worldbank.org/indicator/NY.GDP.MKTP.KD.ZG?locations=EU (data zvernennia 18.07.2020) [in English].

21. Honcharuk, I.V. (2020). Vyrobnytstvo biohazu v ahrarnomu sektori shliakh do pidvyshchennia enerhetychnoi nezalezhnosti ta rodiuchosti gruntiv [Biogas production in the agricultural sector is a way to increase energy independence and soil fertility]. Ahrosvit - Agrosvit, 15, 18-29. Retrieved from DOI: 10.32702/23066792.2020.15.18 [in Ukrainian].

22. Honcharuk, I.V. (2017). Rol silskohospodarskykh kooperatyviv u zabezpechenni staloho rozvytku silskykh terytorii Vinnytskoi oblasti [Role of agricultural cooperatives in providing sustainable development of rural areas of Vinnytsia region]. Ekonomika, finansy, menedzhment - Economy, finances, management, 8(24), 56-67 [in Ukrainian].

\section{Відомості про автора}

ГОНЧАРУК Інна Вікторівна - кандидат економічних наук, доцент кафедри економіки Вінницького національного аграрного університету (вул. Сонячна, 3, м. Вінниця, 21008, email: vnaunauka2020@ gmail.com).

HONCHARUK Inna - PhD in Economics, Associate Professor, Department of Economics, Vinnytsia National Agrarian University (21008, Vinnytsia, 3 Soniachna st, e-mail: vnaunauka2020@ gmail.com).

ГОНЧАРУК Инна Викторовна - кандидат экономических наук, доцент кафедры экономики Винницкого национального аграрного университета (ул. Солнечная, 3, г. Винница, 21008, vnaunauka2020@gmail.com). 